\title{
CONTRIBUTION TO THE TAXONOMY AND PHYLOGENY OF THE GENUS POLIA OCHSENHEIMER, 1816 (NOCTUIDAE, NOCTUINAE, HADENINI): SPECIES GROUPS AND PAIRS IN THE HOLARCTIC SUBGENUS POLIA S. STR.
}

\author{
Zoltán Varga ${ }^{1 *}$, Gábor Ronkay ${ }^{2}$, Jenô Nagy ${ }^{1}$ and László Ronkay ${ }^{3}$ \\ ${ }^{1}$ Department of Evolutionary Zoology and Human Biology, University of Debrecen \\ H-4010 Debrecen, Hungary; E-mails: varga.zoltan@science.unideb.hu, jenonagy.off@gmail.com \\ ${ }^{2}$ Heterocera Press Ltd., H-1137 Budapest, Szent István krt.4, Hungary \\ E-mail: gaborronkay@gmail.com \\ ${ }^{3}$ Department of Zoology, Hungarian Natural History Museum \\ H-1088 Budapest, Baross u. 13, Hungary; E-mail: ronkay.laszlo@nhmus.hu
}

We review the phylogenetic and biogeographical connections of the Holarctic subgenus Polia, re-considering the diagnoses of the species groups based on the external morphology and the characterisation of the male and female genitalia, as well. We produced trees based on genital morphological characters. A preliminary CO1 consensus tree was also constructed which generally supports the morphologically outlined species groups. The plesiomorphic abdominal brush organ was observed to become lost in different species groups independently. The asymmetrisation of the tufts of bristles on the saccular extensions represents one of the most important traits of the genus. These are weakly differentiated, and the shape is nearly symmetrical in supposedly plesiomorphic character states. The most differentiated asymmetrical saccular processes were found in P. serratilinea and, parallel, also in the species of the Holarctic P. nebulosa group. Holarctic connections are present in most Arctic-Boreal species and certain sister species and/or species groups in temperate taxa (i.e. in the P. bombycina and the P. nebulosa species groups), with subsequent speciation in the Nearctic. It means that Trans-Beringian migrations should have occurred at least three times in the geographical history of Polia, from which the trans-migration of the basally split $P$. nebulosa group was the most ancient.

Key words: diagnosis, consensus tree, genital morphology, character status, sister species, biogeography, Polia, Noctuidae.

\section{INTRODUCTION \\ Preliminary considerations on phylogeny and biogeography}

In a recent review paper (VARGA et al. 2017) we considered the taxonomic subdivision of the genus Polia, providing an annotated checklist of the Palaearctic species, the descriptions of three new subgenera, and the re-definition of the nominotypical subgenus Polia s.str. This latter subgenus has, however, a Holarctic distribution; therefore we intend to consider here the phylogenetic and biogeographical connections of the entire group. The importance of Trans-Holarctic connections in the formation of the Noctuidae fauna of arctic 
and boreal Eurasia and North America was discussed in detail at the end of the last century (e.g. Lafontaine \& Wood 1988, Lafontaine \& Kononenko 1988, Kononenko et al. 1989, 1996, Lafontaine et al. 1983, 1987, 1991, Мiккоla et al. 1991). The existence of such connections was already revealed, however, in the earlier survey of Heydemann (1944) on the so-called "Dualspezies" of the genus Polia (syn.: Aplecta Guenée, 1850). Heydemann provided a detailed diagnosis of the genus, including the external morphology and the characterisation of the male and female genitalia, as well. The diagnosis of the genus, together with certain allied genera ('Polia complex') was reviewed by McCABE (1980), summarising in keys the external and genitalia characters.

From the diagnosis of the male genitalia, we have to exhibit the following characters. Dorsal arm of valvae is strongly sclerotised with well-developed cucullus, bearing some bristles of corona and a single (or exceptionally two) angular thorn(s); clavus is fused with the dilated baso-dorsal margin of the sacculus; saccular processes are moderately or strongly elongate, usually with more or less asymmetrical tufts of strong and long, fixed bristles; harpe is most often reduced to its basal plate, only a few exceptions are known; ampulla is, like a clasper, usually present; juxta is medio-dorsally more sclerotised and extended; aedeagus elongate, regularly with bill-shaped ventral carinal sclerotisation; vesica tubular, coiled or retroflexed (in one case helicoidal), with a subbasal and most often also with a medial diverticulum and a variably long distal field of fasciculate cornuti.

In the female genitalia, antrum is broad, sclerotised, often funnel-shaped; ductus bursae is elongate and flattened, moderately or strongly sclerotised; corpus bursae is ample, saccate, generally with three, but often four, mostly weak signa, sometimes with some individual variation within a species; appendix bursae is tubular or conical, posteriorly directed.

According to these diagnoses, the presence of the basal abdominal brush organ belongs to the general, plesiomorphic characters of the genus. This statement is supported by the presence of the brush organ in the closely related Himalayan-Sino-Tibetan genera Haderonia Staudinger, 1896, and Tricheurois Hampson, 1905, but also in the supposedly most ancestral Himalayan-SinoTibetan subgenera of Polia, Protopolia Varga, Ronkay et Ronkay, 2017, Atropolia Varga, Ronkay et Ronkay, 2017 and Metallopolia Varga, Ronkay et Ronkay, 2018 (see VARGA et al. 2017, 2018). This plesiomorphic organ can become lost, however, in Polia s. str. in several independent cases, e.g. (i) in the taxonomically rather distinct, autapomorphic lineage of $P$. serratilinea Treitschke, 1825 which possesses terminally asymmetrical saccular extensions, (ii) in the morphologically rather distinct southern Siberian species, P. malchani (Draudt, 1934), (iii) in three, not closely related species of the P. nebulosa (Hufnagel, 1766) species-group: the Central Asiatic P. lama (Staudinger, 1896) and the 
North American species P. nimbosa (Guenée, 1852) and P. imbrifera (Guenée, 1852), furthermore (iv) in the closely related genus Pachetra Guenée, 1841.

The asymmetrisation and subdivision of the tufts of bristles on saccular extensions represent one of the most important traits of the genus (McCABE 1980). These are in plesiomorphic character stage only weakly differentiated and nearly symmetrical in certain, supposedly phylogenetically ancestral species as P. hepatica (Clerck, 1759), P. subcontigua (Eversmann, 1852), and completely reduced in P. griseifusa Draudt, 1950. The most differentiated asymmetrical saccular processes can be found in the polytypic species $P$. serratilinea and, obviously independently, in the Holarctic P. nebulosa species group (the Nearctic species are discussed in detail in McCABE (1980)). While in other species groups the tuft of bristles on the left saccular process is not (e.g. in the arcto-boreal species: Polia richardsoni (Curtis, 1835), P. rogenhoferi (Möschler, 1870) and P. lamuta (Herz, 1903)) or only weakly subdivided (e.g. in the $P$. bombycina-purpurissata species group), it is clearly separated into a basal and terminal tuft in the species of the P. nebulosa species group (MCCABE 1980).

The molecular data (ZAHIRI et al. 2014) strongly support that the Palaearctic P. bombycina (Hufnagel, 1766) has two Nearctic sister species, P. purpurissata (Grote, 1864) and P. nugatis (Smith, 1898). This relation, however, was already hypothesised by MCCABE (1980) in connection with the Eurasiatic origin of the whole subgenus Polia. Nearctic connection of the expansive Trans-Palaearctic species, P. nebulosa was also suggested by Heydemann (1944), since P. nimbosa was considered by him as a subspecies of $P$. nebulosa. The Sino-Pacific P. goliath (Oberthür, 1880) and the Central Asiatic P. lama were considered as further members of the P. nebulosa species group (VARGA et al. 2019).

Biogeographically, the entire subgenus is exclusively Holarctic. However, only one single polytypic species, $P$. richardsoni, has an entire disjunct circumpolar, Holarctic distribution. Another polytypic species, P. lamuta has an arctic (Siberian)-alpine range. Similarly, one-one species have Nearctic sub-arctic ( $P$. rogenhoferi) and boreal (P. propodea McCabe, 1980) distribution (McCabe 1980). Relatively few species are Trans-Palaearctic, as $P$. hepatica, $P$. bombycina and P. nebulosa. The taxonomically fairly isolated, polytypic $P$. serratilinea has a wide West and Central Asiatic montane steppe and European montane distribution. A set of species is connected with the montane areas of Central Asia and Southern Siberia: P. subcontigua, P. malchani (Draudt, 1934), P. tiefi Püngeler, 1914, P. vespertilio (Draudt, 1934), and P. vesperugo (Eversmann, 1856). These species are closely related with the relic-like West Chinese species, $P$. atrax Draudt, 1950 . The Siberian montane species, occurring in the Altai-Sayan region, were allied by Heydemann (1944) to the arcto-boreal species group as a "Nordgruppe" which seems to be acceptable according to their external and genital morphological features. 
After these preliminary considerations, we have to answer the following questions:

- Which characters can be qualified as the most important synapomorphies (i) of the genus, and (ii) of the monophyletic species groups within the genus, respectively?

- How to distinguish these from the homoplasies?

- Which are the identical basal branches of the morphological and molecular trees?

- Which are the nodes of divergence in Holarctic species groups?

- Do they agree with the formerly established species groups of HeYdeMANN (1944) and MCCABE (1980)?

- Which are the endemic vs. expansive (polycentric) species?

- Which are the monophyletic species groups and/or sister species with Trans-Beringian connections?

- What is the relative chronological sequence of these Trans-Beringian connections?

\section{MATERIAL AND METHODS}

The method of our surveys was basically classical taxonomic, but using all modern facilities from electronic databases and large collection of digitalised microscopic slides to molecular surveys (CO1 gene of mtDNA), since we worked with conserved museum material. The results of scanning electron microscopic surveys on Polia antennae will be published separately.

For morpho-taxonomic studies, we collected and evaluated the photographic documentation of comprehensive type materials and other important voucher specimens of Poliina species from several internationally valuable European collections (Berlin, Bonn, Budapest, London, Munich, Vienna, and St. Petersburg). We established the biogeographical character of all Polia species based on the information harboured in an electronic database of the distribution data. From all species, we prepared a series of standardised genital slides with special consideration on type specimens. As a consequence, we designated several lectotypes, recognised, and stated synonymies and composed a morphological matrix of genital characters (Appendices).

Using the genital morphological data matrices, we produced trees based on these characters (Figs 26-27 and Appendices 1 \& 2). Two independent runs were allowed on data for females and males, separately, iterating for 10,000,000 generations logging every 1000 . The Mkv model (Lewis 2001) for morphological data available in BEAST v2.4.7. (BoucKAERT et al. 2014) was applied in all sets. Maximum clade credibility trees were created from 10,000 trees after removing 10\% (50\% for combined) burn-in using TreeAnnotator v2.4.7 (Bouckaert et al. 2014) for males only (1), for females only (2), and for males and females combined (3).

For our molecular taxonomic investigations, we collected the sequence data of all accessible Poliina species from published barcoding results of the North American, Central and Northern European species, and the known gene bank sequences (Fig. 28). Sequences for cytochrome c oxidase subunit 1 (CO1) were gathered from GenBank (http:// ncbi.nlm.nih.gov/). The average length of available DNA sequences was 649.2 base pairs, 
Table 1. GenBank access numbers of analysed species.

\begin{tabular}{lc}
\hline Species & $\begin{array}{c}\text { GenBank ac- } \\
\text { cess number }\end{array}$ \\
\hline Atropolia (Polia) mortua & $\mathrm{JX} 392419$ \\
Pachetra sagittigera & $\mathrm{J}$ 4415636 \\
Polia bombycina & GU654989 \\
P. conspicua & KT782711 \\
P. discalis & KJ388193 \\
P. hepatica & HQ955372 \\
P. imbrifera & GU090125 \\
P. lamuta & KT782486 \\
P. nebulosa & HQ565374 \\
P. nimbosa & GU090128 \\
P. nugatis & HM868477 \\
P. piniae & HM423859 \\
P. propodea & GU097066 \\
P. purpurissata & GU091372 \\
P. richardsoni & KJ385234 \\
P. rogenhoferi & HM375704 \\
\hline
\end{tabular}

however, we used the longest sequence of all species with a length of 658 base pairs each (accession numbers listed in Table 1). This sequence length is corresponding to similar studies (e.g. Huemer et al. 2014, Zahiri et al. 2014). MAFFT (КАтон et al. 2005) was applied for aligning gene sequences. Then the alignments were cleaned with Gblocks (CAsTRESANA 2000). The 'ape' (PARADis et al. 2004) and 'seqinr' (Charif \& Lobry 2007) packages in R v3.4.1 (R Development Core Team 2017) were used to facilitate these steps.

A maximum likelihood approach (RAxML, Stamatakis 2006) was applied to find the starting tree for the Bayesian MCMC analyses conducted in BEAST v1.8.3 (DrumMOND \& RAmbaut 2007). The best-fitted substitution model $(\mathrm{GTR}+\mathrm{G}+\mathrm{I})$ according to the model test available in the 'phangorn' package (Schlies 2011) was set, and a birthdeath model of speciation was applied in the analyses (Gernhard 2008). Two independent BEAST runs were allowed iterating for $50,000,000$ generations logging every 5000. A maximum clade credibility tree was created from 20,000 trees after removing $10 \%$ burnin using TreeAnnotator v1.8.3. (RAmbaut \& Drummond 2016). Effective samples sizes were checked in Tracer v1.7.6. (RAmbaut et al. 2018), for the analyses based on morphological and also on genetic data, which allowed evaluating the initial settings for the MCMC runs.

\section{RESULTS}

\section{Character analysis and phylogenetic interpretation}

According to the genital morphology of both sexes, Polia (s.l.) is primarily subdivided with full support into two main branches: (i) the nebulosa clade vs. (ii) all other species groups. Within the latter, more heterogeneous group the monophyly of the Pachetra-Metallopolia twin clade is mostly supported which share (i) the symmetric shape of clasping apparatus and (ii) the elongate, in Pachetra also spiralled vesica, without diverticula and covered by extremely numerous, nearly evenly dispersed tiny spinulose cornuti (Figs 26-27). The coherence of the externally rather diverse $P$. (Atropolia) mortua (Staudinger, 1888) - P. hepatica - P. griseifusa - P. subcontigua complex is also strongly supported (Figs 26-27). These species are also characterised by the plesiomorphic, symmetrical character state of valvae without differentiation of saccular 
bristles, as the widespread $P$. hepatica and P. subcontigua, or the West Chinese endemic $P$. griseifusa with reduction of bristles. Furthermore, $P$. hepatica also shows a helicoidal configuration of the long, tubular vesica (Fig. 1), and, in female, the co-adapted sausage-shaped appendix bursae. These traits are pre-

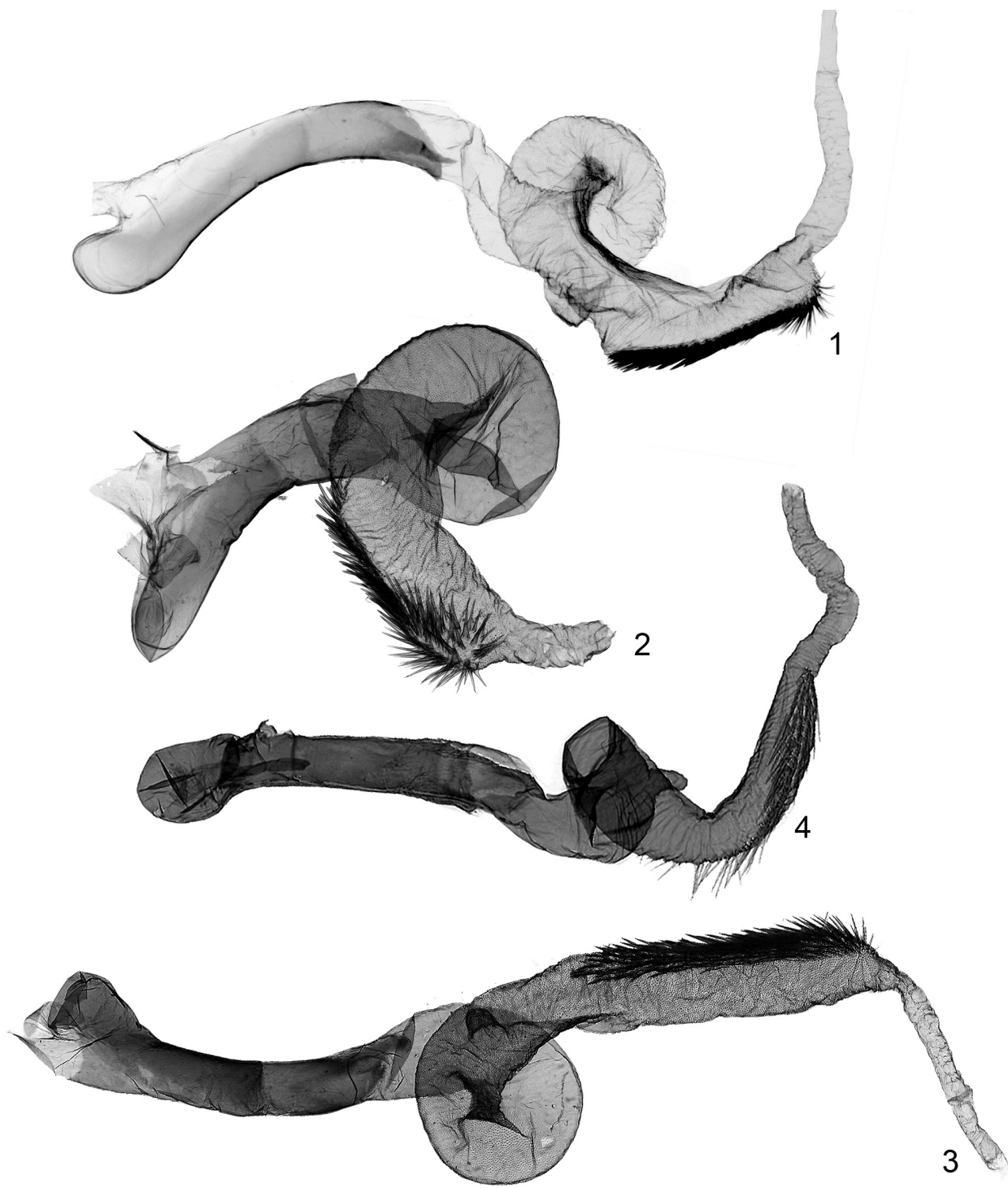

Figs 1-4. Male aedeagus of Polia complex: 1 = Polia hepatica (Clerck, 1759), slide no. RL12391, Czech Republic, 2 = Haderonia iomelas (Draudt, 1950), slide no. VZ8003, China, Sichuan, 3 = Ctenoceratoda sukharevae (Varga, 1974), slide no. VZ9239, Mongolia, 4 = Tricheurois cuprina (Moore, 1881), slide no. VZ9234, Nepal 
sent in somewhat similar appearance also in certain other genera of Poliina as Haderonia, Ctenoceratoda Varga, 1992 and Tricheurois (Figs 2-4) sharing also the plesiomorphic symmetrical character of the genital capsule. It is worth to note that an extreme form of the helicoidal configuration of vesica is present in the other widespread species, P. subcontigua, combined with the reduction of the subterminal fascia of cornuti as a unique derived character.

The saccular processes are relatively short and without well-differentiated tufts of bristles in the also otherwise distinct species $P$. subcontigua, $P$.
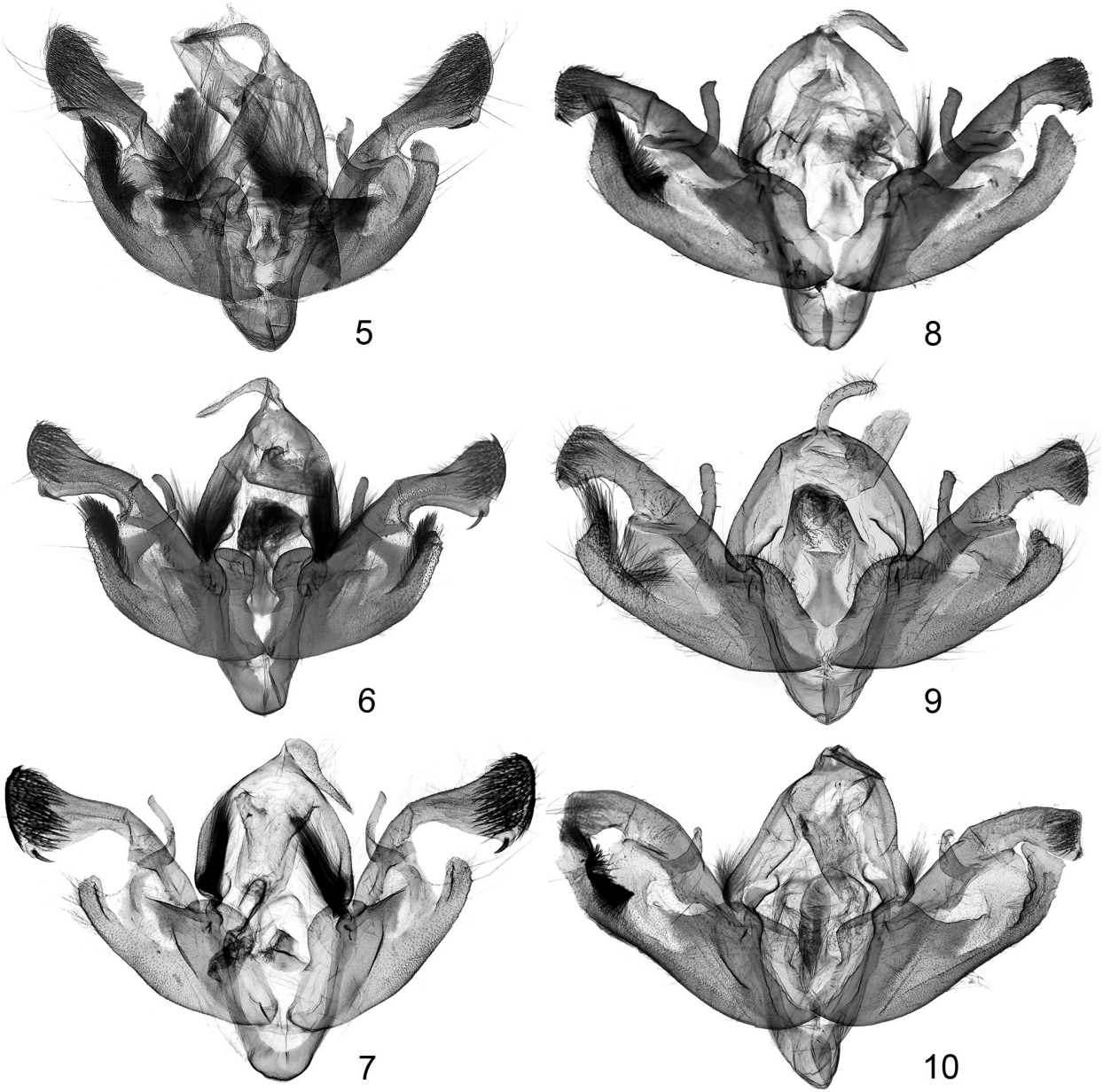

Figs 5-10. Male genital capsula of Polia species: 5 = Polia subcontigua (Eversmann, 1852), slide no. VZ9175, Kirghisia, 6 = P. hepatica (Clerck, 1759), slide no. RL12396, Mongolia, 7 = P. griseifusa (Draudt, 1950), slide no. VZ9523, China, Sichuan, $8=$ P. lamuta (Herz, 1903), slide no. VZ8266, Sweden, 9 = P. richardsoni (Curtis, 1835), slide no. RL12012, Greenland, 10

= P. rogenhoferi (Möschler, 1870), slide no. VZ8970, North America 
hepatica and $P$. griseifusa (Figs 5-7). In all other species, there are some obvious trends in the asymmetrisation of the genital capsule and - possibly as a tradeoff - in the simplification of the vesica. The saccular processes are somewhat more elongate and are bearing a brush of stronger bristles only on the left side in the arctic-boreal species group: P. lamuta, $P$. richardsoni and $P$. rogenhoferi
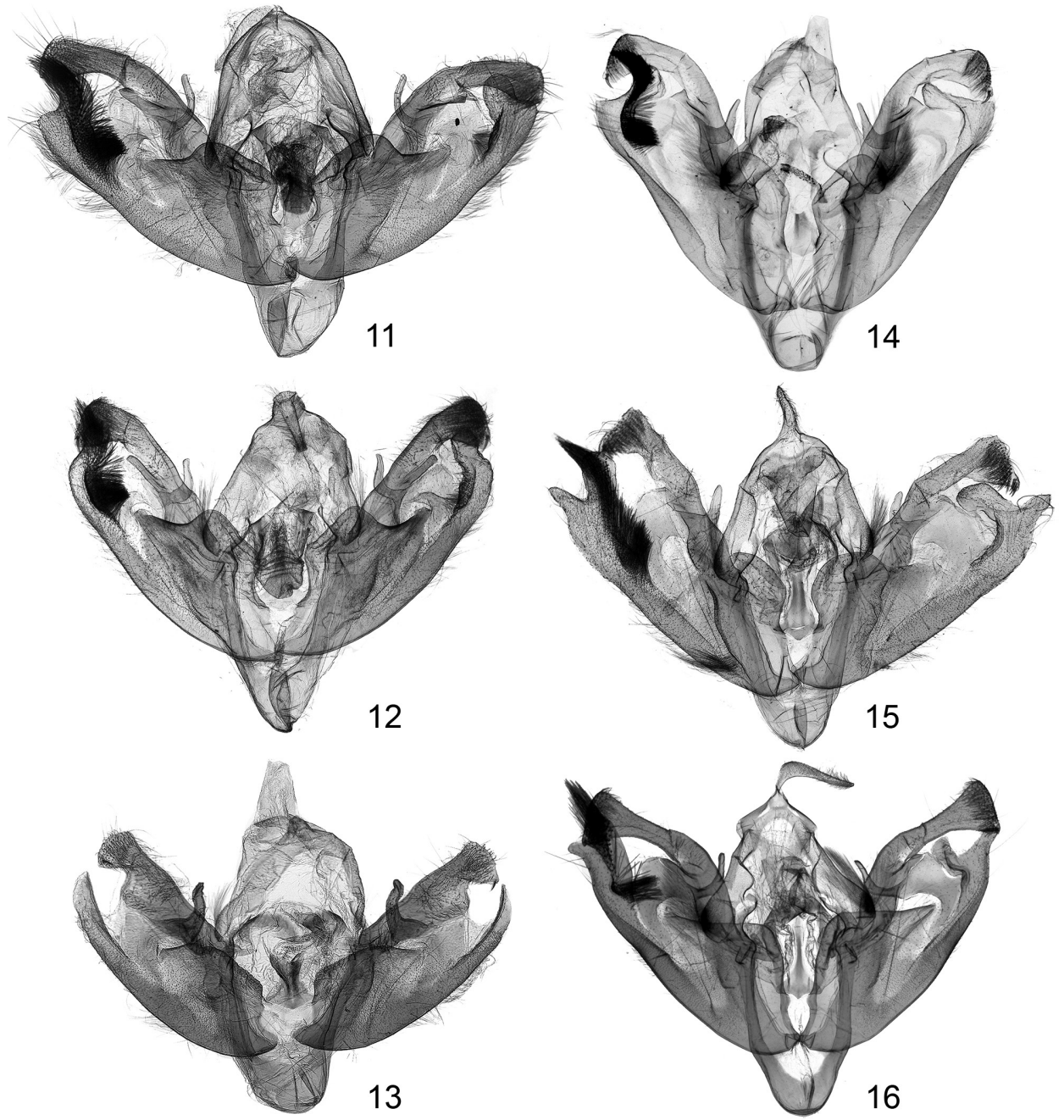

Figs 11-16. Male genital capsula of Polia species: $11=P$. tiefi Püngeler, 1914, slide no. VZ9792, Russia, Buryatia, $12=$ P. vespertilio (Draudt, 1934), slide no. VZ9954, Mongolia, $13=$ P. malchani (Draudt, 1934), slide no. VZ9779, Mongolia, $14=P$. vesperugo Eversmann, 1856, slide no. VZ2/72, Sayan Mts (holotype of Mamestra conspicua Bang-Haas, 1912), $15=$ P. propodea McCabe, 1980, slide no. VZ8969, North America, $16=$ P. serratilinea (Treitschke, 1825), slide no. KÁ1586, Greece 

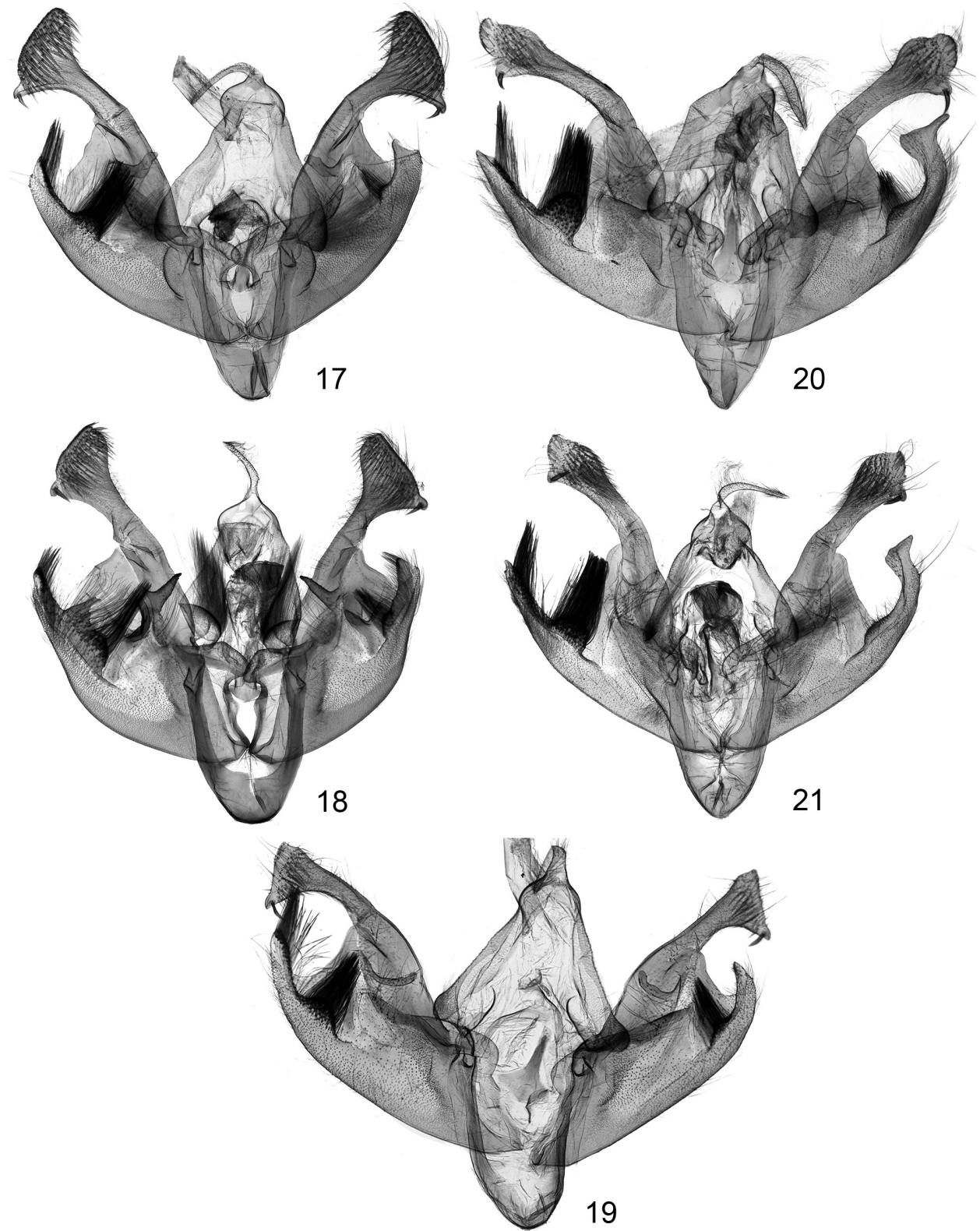

Figs 17-21. Male genital capsula of Polia species: 17 = P. goliath (Oberthür, 1880), slide no. RL11031, North Korea, $18=$ P. nebulosa (Clerck, 1759), slide no. RL12419, Czech Republic, $19=$ P. lama (Staudinger, 1896), slide no. VZ9783, Kirghisia, $20=$ P. discalis (Grote, 1877), slide no. VZ8972, North America, $21=$ P. piniae Buckett et Bauer, 1967, slide no. VZ9944, Canada 

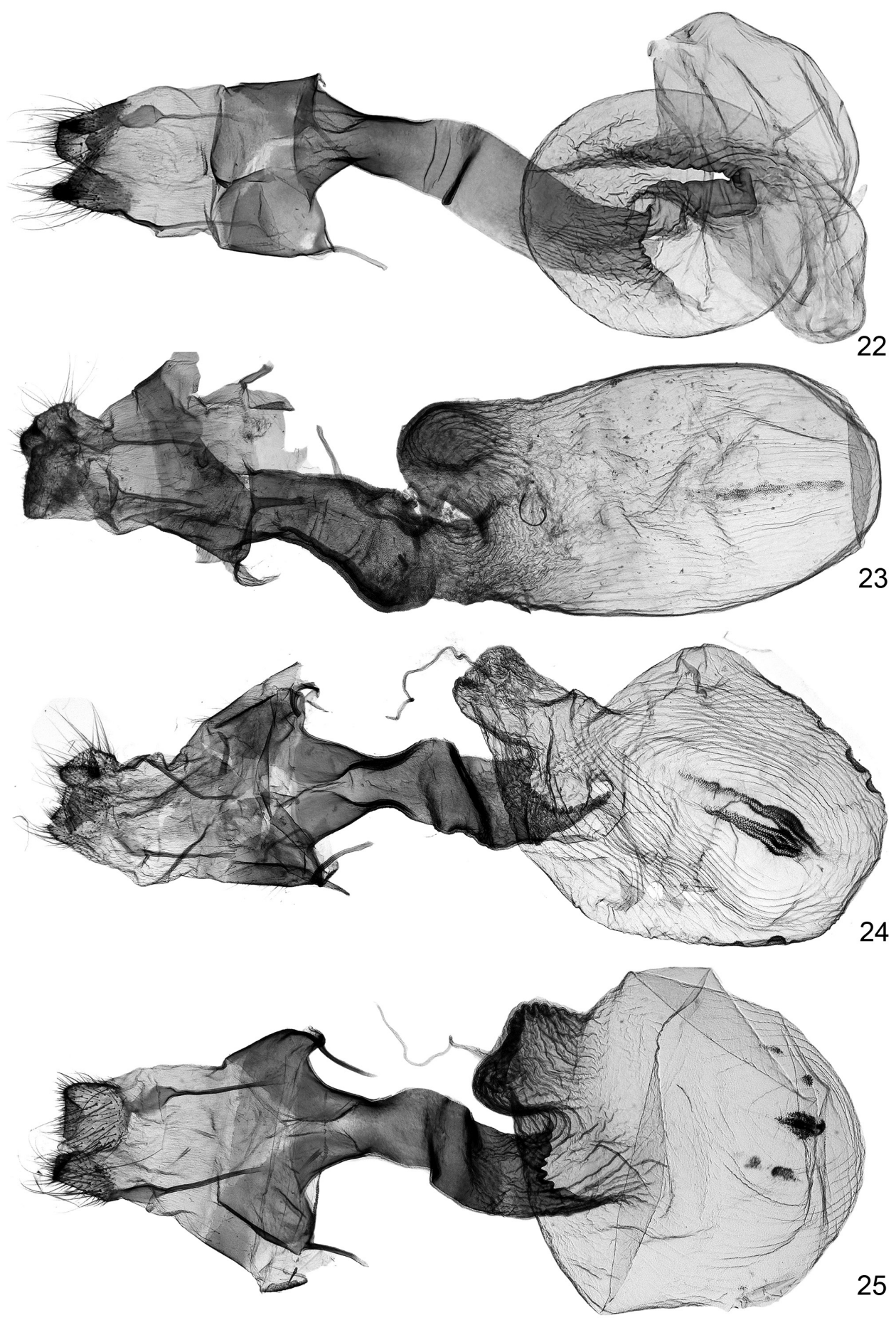
(Figs 8-10). This "triplet" of species is also strongly supported on the genital morphological trees (Appendices 1-2). The diverse "Siberian" species group seems to be closely allied to the former species since they also have a bundle of strong bristles only on the left saccular process and the bristles on the left side are not differentiated into two tufts (Appendices, Figs 26-27). The processes are, however, more differentiated in the species of this group, i.e. these are often more or less spatulate $(P$. tiefi, $P$. vespertilio, Figs $11-12)$ or obtuse $(P$. malchani, Fig. 13) on the left side, and the terminal part of the right process shows a moderate trend of bifurcation ( $P$. vesperugo, $P$. tiefi). This character is also present in the North American $P$. propodea which appears as a strongly supported sister species of $P$. vesperugo (Figs 14-15, Figs 26-27). The bifurcation of the terminal part of the right process is manifested in extreme form in the externally dissimilar $P$. serratilinea (Fig. 16), also characterised by a subdivision of bristles on the left process.

The former, mostly boreo-montane group is closely allied with the Holarctic P. bombycina "triplet" of species. The monophyly of the Trans-Palaearctic, polytypic $P$. bombycina and its Nearctic sister species-pair, P. purpurissata and P. nugatis is also strongly supported (Figs 26-27). These species show some trend of subdivision of bristles into two tufts on the left saccular process and also the appearance of some stronger bristles on the right side, mostly in $P$. purpurissata, at least in $P$. nugatis, and rather variable in different populations (subspecies?) of $P$. bombycina.

Concerning the genital structures of both sexes, the $P$. nebulosa species group proved to be the most homogenous group (Figs 26-28) in which all species show a perfect separation of bristles on the left process into a subbasal and terminal group (Figs 17-21), and the appearance of a subbasal group of bristles on the right side. The vesica is characterised in this group by the presence of a subbasal and a medial diverticulum. The distinctness of this group was already indicated by CO1 data (ZAHIRI et al. 2014).

Abdominal brush organ (coremata) are generally present, both in the morphologically "basal" groups as in all Metallopolia species but also in P. hepatica, P. subcontigua. They are also present in the species of the other groups, with some exceptions, e.g. P. malchani in the Siberian group, in the Eurasiatic mountain steppe $P$. serratilinea, and also in three not closely related species of the nebulosa species group, i.e in the Central Asiatic P. lama and in the North American P. nimbosa and P. imbrifera.

Figs 22-25. Female genitalia of Polia species: $22=P$. hepatica (Clerck, 1759), slide no. RL12394, Austria, $23=P$. vespertilio (Draudt, 1934), slide no. VZ9972, Russia, Transbaikalia, $24=P$. imbrifera (Guenée, 1852), slide no. VZ9969, Canada, 25 = P. lama (Staudinger, 1896), slide no. RL12347, Kirghisia 
The configuration of the female genitalia is rather uniform. Papillae anales are usually weakly sclerotised, rounded or obtuse, never acute. The whole antrum-ductus bursae-corpus bursae + appendix bursae apparatus is co-adapted to the elongate aedeagus and elongate tubular vesica. Ductus bursae is the shortest in the arctic-boreal species $P$. richardsoni, P. lamuta and $P$. rogenhoferi, and the longest, with mostly extended, funnel shaped antrum is present in the supposedly mostly derived P. nebulosa group (Figs 21-24). Unfortunately, in presence vs. absence of signa we could not find any phylogenetic trend since the presence vs. reduction of this trait was rather eclectic in the different species groups and in closely related species, as well. Some variations were also observed even within one single species, in accordance with the previous findings of McCABE (1980).

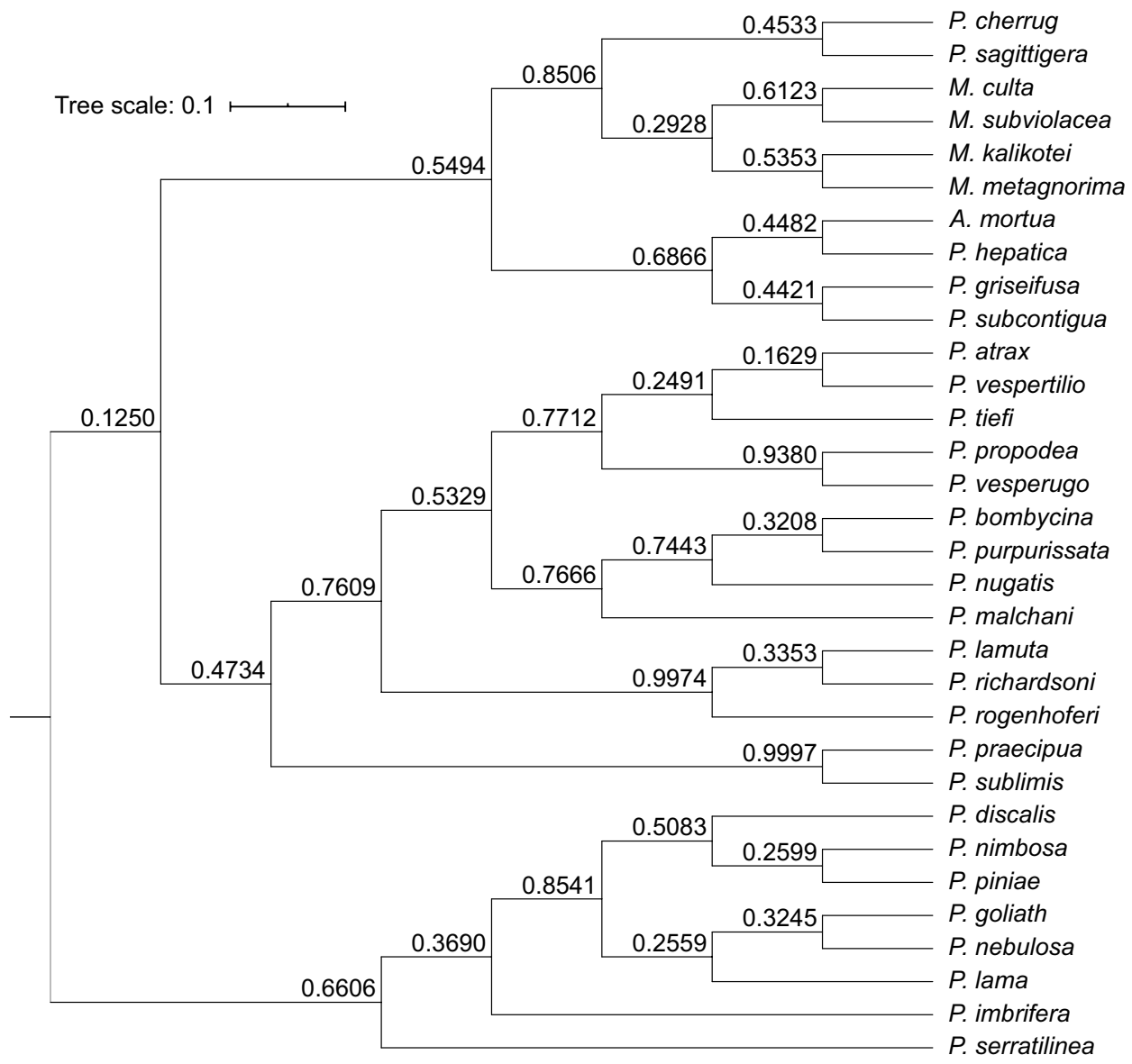

Fig. 26. Consensus tree based on discrete character data of male genitalia 


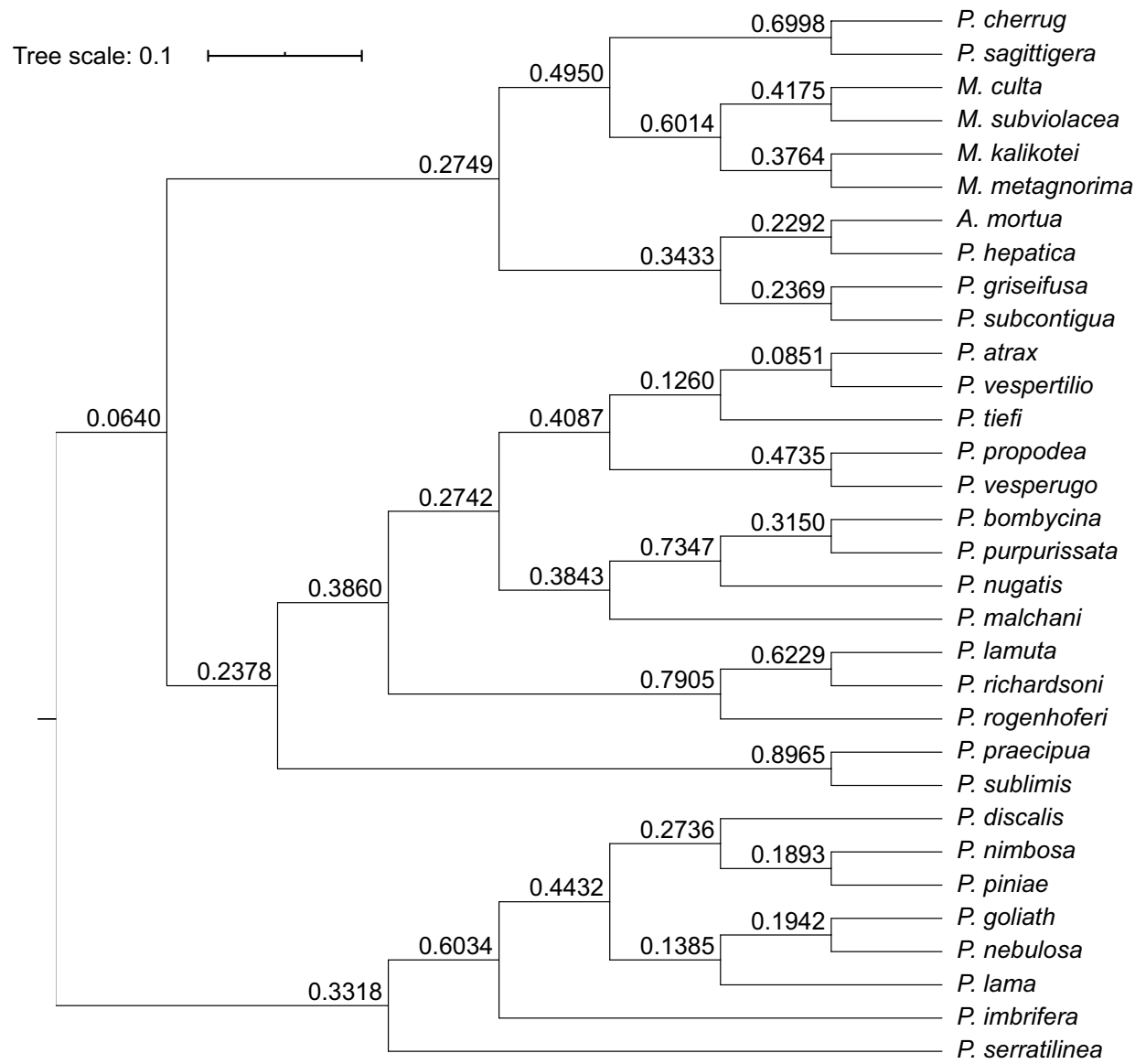

Fig. 27. Consensus tree based on discrete character data of male and female genitalia

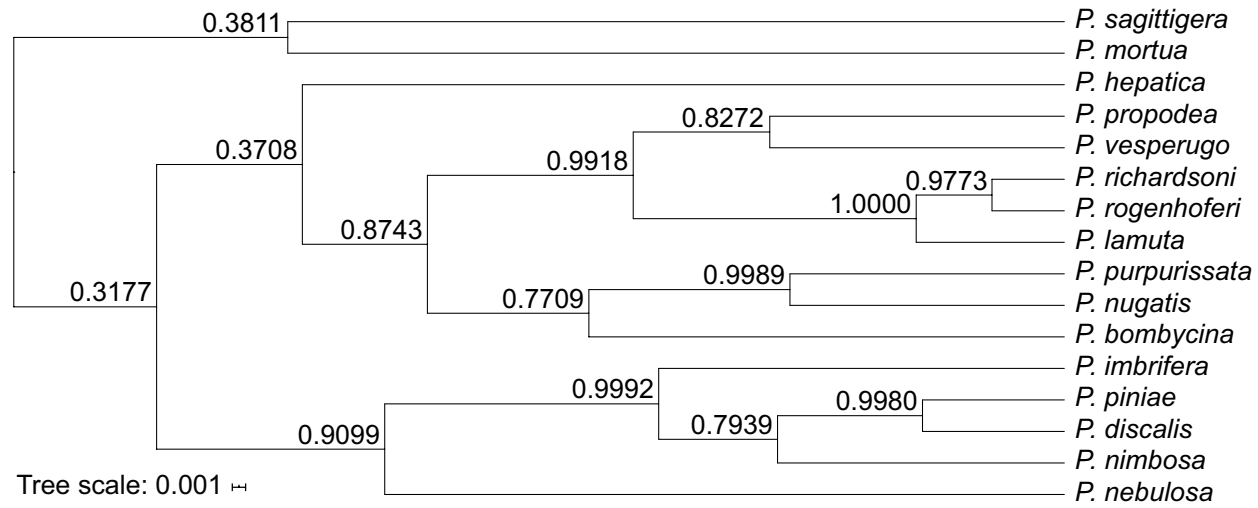

Fig. 28. Tree constructed from published barcoding results of the North American, Central and Northern European species, and the known gene bank sequences 
According to our preliminary survey based on the CO1 gene our results can be summarised as follows. Since Pachetra sagittigera and P. (Atropolia) mortua appear as outgroup of Polia s. str., the subgenus Polia can be considered as a monophyletic taxonomic unit (Fig. 28). Within Polia the basal split was observed between the "nebulosa group" and all other Polia species, in full agreement with our morphological analysis and with the earlier traditional taxonomic and molecular works (Heydemann 1944, MCCABE 1980, ZAhiri et al. 2014). In the nebulosa species group the Eurasiatic nebulosa species group seems to be the sister group of all Nearctic species in which $P$. imbrifera is separated from the other three species with a high support. Unfortunately, the Central Asiatic $P$. lama could not be considered failing the necessary molecular data.

In the other group of species, $P$. hepatica has shown the basal split which is plausible also according the plesiomorphic characters of the genital capsule and the helicoidal configuration of the long, tubular vesica (see also Trees 1-3). The other species are subdivided into two main groups: the mostly boreal (Siberian) and arctic species as opposed to the species triplet of the temperate Holarctic nebulosa species group which is also well-founded both on the morphological characters and geographical distribution of species. In this group $P$. purpurissata and P. nugatis are well-differentiated sister species as opposed to the widely distributed Eurasiatic $P$. bombycina. In the boreo-arctic group the species triplet $(P$. lamuta $+P$. richardson $+P$. rogenhoferi $)$ is clearly separated from the $P$. propodea-P. vesperugo pair. However, the Siberian species which are close to the latter group ( $P$. tiefi, $P$. vespertilio and $P$. malchani) remained unconsidered due to lack of the available barcode sequences.

\section{REVISED TAXONOMICAL SUBDIVISION OF THE SUBGENUS POLIA}

Summarising the results of the morphological characters and the preliminary molecular tree based on the barcode gene, we suggest the following taxonomic grouping of Polia s. str. species with some biogeographical comments.

\section{Subgenus Polia Ochsenheimer, 1816}

Polia Ochsenheimer, 1816, Die Schmetterlinge von Europe 4: 73. Type-species: Phalaena nebulosa Hufnagel, 1766, by subsequent designation by Curtis, 1829 .

Taxonomically distinct Eurasiatic species without North American connections

Taxonomic notes. The following three species are not closely related to each other. They only share some similar plesiomorphic characters as the nearly symmetrical configuration of the male genital capsule with short saccular 
processes, and the strong, sclerotised ampulla. Abdominal brush organ usually present. Two species are also clearly differentiated according to the sequence of the CO1 gene; furthermore P. hepatica shows a basal separation within Polia s. str. The barcode sequence of $P$. griseifusa is unfortunately unknown.

\section{Polia (Polia) hepatica (Clerck, 1759)}

Phalaena hepatica Clerck, 1759, Icones Insectorum Rariorum cum Nominibus eorum Trivialibus, Locisque e C. Linnaei 1: pl. 8, fig. 3. Type-locality: [?Europe] no locality given.

Taxonomic notes. This species is somewhat similar to the former one in the general shape of genital capsule but the bundle of bristles on saccular processes is slightly more expressed on both sides. The vesica has a subbasal and subterminal helicoidal torsion but with a typical, long stripe of fasciculate cornuti. The species has an extended boreo-nemoral, Trans-Palaearctic distribution with numerous colour forms but without any clear subspecific subdivision.

\section{Polia (Polia) griseifusa Draudt, 1950}

Polia griseifusa Draudt, 1950, Mitteilungen der Münchner Entomologischen Gesellschaft 40: 30, pl. 2, fig. 14. Type-locality: China, Prov. Yunnan, Li-kiang. Lectotype, female, in coll. ZFMK.

Taxonomic notes. This species is allied to the former one according to its external look and genital capsule. However, the bristles of the saccular processes are on both sides reduced. The configuration of the vesica is rather different, simply retroflexed dorsally with strong sclerotisation on the inner side and with a centrally positioned stripe of fasciculate cornuti. This species is known from W China (Yunnan, Sichuan) only and seems to be rather rare.

\section{Polia (Polia) subcontigua (Eversmann, 1852)}

Hadena subcontigua Eversmann, 1852, Bulletin de la Société Imperiale des Naturalistes de Moscou 25 (1): 155. Type-locality: [Russia, Orenburgskaya obl.] "Spask.[oye]" "Jul[y]" (handwritten labels). Holotype: female, in coll. ZISP.

Taxonomic notes. This species is identical with the well-known P. altaica (Lederer, 1853), including the f. monotona (Bang-Haas, 1912); the synonymy was established by VARGA et al. (2017). Most populations of the species are polymorphic with variable proportion of contrastingly patterned ("typical") vs. concolorous ("monotona") forms without a clear geographical trend on the most part of the range with the exception of the Himalayan region where the 
dark fuscous form predominate (Boursin 1964). The male genital capsule is nearly symmetrical with short saccular extensions but with a group of strong bristles on the left side only. Vesica is tubular, triple helicoidal, without any stripe of spinulose cornuti.

The name subcontigua was forgotten until the recent times, and the species was generally cited under the name altaica. This polymorphic species has a wide but scattered range, and is distributed from the southern Urals to Nepal on the one side and to Mongolia on the other.

\section{Holarctic boreo-arctic-alpine group}

Taxonomic notes. The following three species have essentially similar genitalia. In males, saccular processes nearly symmetrical, obtuse with a stripe of strong bristles on the left side only; ampulla strongly sclerotised, relatively thick, terminally rounded or obtuse; vesica relatively simple, upturned dorsally, with a short stripe of fasciculate cornuti and with a small, tubercle-shaped medial diverticulum only; abdominal brush organ usually present. In females, ductus bursae relatively short, corpus bursae without signa, appendix bursae semiglobular, slightly incurved. The first two species are day-active, they have whitish hindwings with black terminal band, the third species is much larger, night-active and externally similar to the species of the next group.

\section{Polia (Polia) lamuta (Herz, 1903)}

Anarta lamuta Herz, 1903, Annuaire du Musée Zoologique de l'Académie Imperiale des Sciences de St.-Pétersbourg 8: 82. Type-locality: [Russia] Uruata Camp place; W of Verkhoyansk. Syntypes: 1 male, 1 female, in coll. ZISP.

Taxonomic notes. The species is subdivided to two, morphologically and geographically clearly separated subspecies. The identity of the nominotypical lamuta with the south Siberian alpine (Sayan Mts) ssp. tunkinski O. BangHaas, 1927 was already suggested by Heydemann (1944) who considered $P$. lamuta rangnowi Püngeler, 1909 from Lapland as valid subspecies.

The ampulla is in P. lamuta lamuta much stronger than in P. l. rangnowi, terminally obtuse.

\section{Polia (Polia) richardsoni (Curtis, 1835)}

Hadena richardsoni Curtis, 1835, Appendix to John Ross Narrative of a Second Voyage 1835: 72, pl. A, fig. 11. Type-locality: [Canada] 15 miles from River Tatchick (Eskimo name), 200 miles S of Port Bowen, very near Comptroller's Island. Types: in coll. USNMW. 
Taxonomic notes. This circumpolar Holarctic species shows intense subspeciation in both continents; the taxonomic status of the described taxa is to be clarified yet.

Polia (Polia) rogenhoferi (Möschler, 1870)

Mamestra rogenhoferi Möschler, 1870, Entomologische Zeitung, Entomologischen Vereine zu Stettin 31: 269. Type-locality: USA, Labrador.

Taxonomic notes. A Nearctic arcto-boreal species with a montane exclave in Colorado.

\section{Southern Siberian-W Chinese species group}

Taxonomic notes. The following species are closely allied to the former group, but they are essentially larger, mostly with dark greyish colouration and suffused markings. They have numerous specializations in the genitalia of both sexes. Saccular processes are more or less asymmetric in shape and they have a compact stripe of strong bristles on the left side only. The end of processes is more or less extended, in P. malchani obtuse. Vesica is relatively simple, curved with a more or less elongate stripe of fasciculate cornuti and with a medial diverticulum. Abdominal brush organ usually present, with the exception of $P$. malchani in which only the pedicel of the organ can be observed. In females, ductus bursae is tubular, mostly strongly sclerotised distally, proximally rugulose or extended, bursa with one stronger, stripeshaped and generally with two weaker signa. The $\mathrm{W}$-Chinese $P$. atrax is possibly the most ancient, relict species of this group.

Polia (Polia) propodea McCabe, 1980

Polia propodea McCabe, 1980, New York State Museum Bulletin No. 432: 18-19. Type-locality:

Canada, Columbia, Mt. Evans, Echo Lake.

Taxonomic notes. According to the external appearance and genital configuration this species is closely related to the next, polytypic, disjunct Palaearctic species. Based on the barcode data they are possibly sister species.

\section{Polia (Polia) vesperugo Eversmann, 1856}

Polia vesperugo Eversmann, 1856, Bulletin de la Société Impériale des Naturalistes de Moscou 29 (3): 48, pl. 2, fig. 6. Type-locality: [Russia] Transbaikalia, Irkutsk. Lectotype: female, in coll. ZISP. 
Taxonomic notes. This species was mentioned in the earlier publications as $P$. conspicua (Bang-Haas, 1912). The synonymy with $P$. vesperugo was stated and the lectotype was designated by VARGA et al. (2017). The geographically separated population groups of the species were originally described as distinct species (Sayan Mts: P. conspicua Bang-Haas, 1912; Russian Far East, Primorye distr.: P. vasjurini Sukhareva, 1976; North Finland, Inari: P. sabmeana Mikkola, 1980). They were considered as subspecies of a Siberian tundro-alpine species by HACKER et al. (2002), based on the presumably much larger distribution of the species (KonONENKO 1990). However, the taxonomic analysis of these externally different populations requires further studies.

\section{Polia (Polia) tiefi Püngeler, 1914}

Polia (Mamestra) tiefi Püngeler, 1914, Deutsche Entomologische Zeitschrift, Gesellschaft Iris zu Dresden 28: 38, pl. 2, fig. 22. Type-locality: [Russia] Sayan Mts, Munko-Sardyk. Lectotype: male, in coll. MNB.

Taxonomic notes. This species was mentioned in the earlier publications as $P$. vesperugo (auct. nec Eversmann, Heydemann 1944, Hacker et al. 2002) or P. schawerdae (Sheljuzhko, 1933). The synonymy with the latter species was established by VARGA et al. (2017). P. tiefi is widely distributed with some variation in the external appearance in the high mountains of NE Kazakhstan, South Siberia and Northern Mongolia (Saur, Tarbagatai, Sayan, Altai, Khangai and Khentij mountains), mostly in the upper mountain taiga zone.

\section{Polia (Polia) vespertilio (Draudt, 1934)}

Aplecta vespertilio Draudt, 1934, in A. Seitz, Die Gross-Schmetterlinge der Erde 3: 109, pl. 14, row i. Type-locality: [Russia], Irkutsk, Tunkinski Mt. Lectotype: male, in coll. MNB.

Taxonomic notes. According to the external look and the configuration of the genitalia of both sexes it can be considered as closely related to the former one.Their distribution is partly overlapping in the southern Siberian and northern Mongolian mountains; however it is more widely distributed both in West (southern Ural Mts) and East (Pacific mountains). Taxonomic interpretation of the Pacific (North Korean) population still requires further studies.

\section{Polia (Polia) malchani (Draudt, 1934)}

Aplecta malchani Draudt, 1934, in A. Seitz, Die Gross-Schmetterlinge der Erde 3: 108, pl. 14, row i. Type-locality: [Russia] Transbaikalia, Malchan Mt, "Borochojewa", 800 m. Holotype: female, in coll. MNB. 
Taxonomic notes. This is the only species of the group where the abdominal brush organ is fully reduced. It has a wide but obviously incompletely known area extending from the southern Ural Mts to the Russian Far East, Korea and Japan, seemingly without any geographical trend of variation.

\section{Polia (Polia) atrax Draudt, 1950}

Polia atrax Draudt, 1950, Mitteilungen der Münchner Entomologischen Gesellschaft 40: 31, pl. 2, fig. 17. Type-locality: China, Prov. Yunnan, Atuntse. Lectotype: male, in coll. ZFMK.

Taxonomic notes. The species includes two geographic subspecies, ssp. atrax (Yunnan) and ssp. vargai Gyulai et Saldaitis, 2017 (Gansu) with slight but seemingly constant differences both in external and genital characters. The bundle of bristles on the left saccular process is already slightly differentiated and the right-sided process is shorter than in other species of this group and also somewhat more obtuse.

\section{Isolated Palaearctic steppic species}

\section{Polia (Polia) serratilinea (Treitschke, 1825)}

Mamestra serratilinea Treitschke, 1825, Die Schmetterlinge von Europa 5 (2): 38. Type-locality: Austria, Vienna district. Lectotype: male, in coll. HNHM.

Taxonomic notes. Numerous subspecies of this externally strikingly variable species are described. The nominotypical subspecies is restricted to the eastern periphery of the Austrian Alps. Further subspecies occur in the Central and western Alps, and Alsace (Mamestra serratilinea helvetica Schawerda, 1925), Balkan peninsula (Polia serratilinea kowatschevi Drenovsky, 1931), Central Anatolia (Polia serratilinea pinkeri Varga, 1974), and more clearly differentiated in Central Asia (Polia serratilinea spalax (Alphéraky, 1887), in the Hindukush-Himalaya area (Polia serratilinea tenebricosa Hacker et Weigert, 1990), but also in western Mongolia (Polia serratilinea eremorealis Varga, 1974).

This species shows some convergence to $P$. propodea in the bifid terminal part of the right saccular process. The two lineages are, however, rather distant by their $\mathrm{CO} 1$ sequences. The asymmetrisation of the clavus and saccular processes show an evident geographical variation; its analysis and taxonomic interpretation will be treated in a further publication. 
The Polia bombycina species-group

Taxonomic notes. The polytypical, Trans-Palaearctic P. bombycina is although closely related but clearly differentiated from the North American species pair $P$. purpurissata and $P$. nugatis both in morphological characters and CO1 sequences (ZAHIRI et al. 2014).

\section{Polia (Polia) bombycina (Hufnagel, 1766)}

Phalaena bombycina Hufnagel, 1766, Berlinisches Magazin 3(4): 410. Type-locality: [Germany] vic. of Berlin. Type(s) destroyed.

Taxonomic notes. The Asiatic populations of P. bombycina clearly show a western-eastern subdivision with some overlap in Mongolia. The west Asiatic group of populations has two contrasting forms (subspecies?) at the eastern edge of the range, (i) the dark bronze-brownish Polia bombycina puengeleri Lehmann, 1998, described from [Kirghisia] Alexander Mts and occurring also in Kazakhstan, and (ii) the pale fawn-coloured Polia bombycina psammochrea Varga, 1974, described from Mongolia, Govi Altai aimak, Khasaght Khajrhan Mts. The taxonomic subdivision of the eastern group (cf. Polia bombycina grisea (Butler, 1878)) described under some different names (see: VARGA et al. 2017) needs further surveys, as well as the populations occurring in the Caucasus range.

\section{Polia purpurissata (Grote, 1864)}

Eurois purpurissata Grote, 1864, Entomological news, and proceedings of the Entomological Section of the Academy of Natural Sciences of Philadelphia 9: 82, pl. 1, fig. 5. Type-locality: USA, Pennsylvania.

Taxonomic notes. The widely distributed North American species shows a considerable geographical variation. However, only P. purpurissata apurpura (Barnes \& McDunnough, 1913) has an allopatric range (Arizona), while "Mamestra languida Smith, 1893" possibly represents a rare hybrid with P. nugatis (see: MCCABE 1980: 24).

\section{Polia nugatis (Smith, 1898)}

Mamestra nugatis Smith, 1898, Proceedings of the Entomological Society of Philadelphia 3: 240. Type-locality: USA, Montana.

Taxonomic notes. A species restricted to the mountainous western parts of the Nearctic in the U.S. and Canada. It has long been considered as con- 
specific with the former species but is differentiated in genitalia of both sexes (McCABE 1980) and co-occurring with P. purpurissata in most parts of its range.

\section{The Polia nebulosa species-group}

Taxonomic notes. The detailed taxonomic and biogeographical survey of the species-group is recently published by VARGA et al. (2019). This group has a wide temperate Palaearctic ( $P$. nebulosa Hufnagel, 1766; P. lama Staudinger, 1896; P. goliath Oberthür, 1880) but also Nearctic distribution (see below). The three Palaearctic species are externally forming two groups as $P$. goliath is strikingly different from the often confusingly similar $P$. nebulosa and $P$. lama though both related species have conspicuous intraspecific differentiation, too. McCAbe (1980) already confirmed that four North American Polia species are closely related to the Eurasiatic P. nebulosa, and this Nearctic group of species is possibly a descendent of the "nebulosa"-lineage. It is differentiated from the P. piniae Buckett \& Bauer, 1967 - P. discalis Grote, 1877 species-pair near to the Pacific coast, while P. nimbosa (Guenée, 1852) and P. imbrifera (Guenée, 1852) are widely distributed in the boreo-temperate zone.

\section{Polia (Polia) nebulosa (Hufnagel, 1766)}

Phalaena nebulosa Hufnagel, 1766, Berlinisches Magazin 3 (3): 298. Type-locality: Germany, Berlin district.

Taxonomic notes. The subspecific splitting of P. nebulosa is published in a separate article (VARGA et al. 2019).

\section{Polia (Polia) lama (Staudinger, 1896)}

Mamestra nebulosa var. lama Staudinger, 1896, Deutsche Entomologische Zeitschrift, Gesellschaft Iris zu Dresden 9: 241. Type-locality: [Mongolia, Khangay Mts] Uliassutay. Holotype: male, in coll. MNB.

Taxonomic notes. The subspecific subdivision of $P$. lama is published by VARGA et al. (2019).

\section{Polia (Polia) goliath (Oberthür, 1880)}

Dichonia goliath Oberthür, 1880, Études d'Entomologie 5: 68, pl. 6, fig. 7. Type-locality: [Russia] Askold [Island]. Holotype: male, in coll. BMNH.

Taxonomic notes. The populations occurring in Taiwan represent a distinct taxon, the description of which will be presented in a separate article. 
The Polia nimbosa-imbrifera species-group

Taxonomic notes. The four Nearctic species are closely allied to the Palaearctic members of the nebulosa group according to their external and genital morphological characters but also according to the sequences of the CO1 gene. The nearly parapatric sister species $P$. discalis and $P$. piniae occur mostly in the region of the Rocky Mountains while the other two species are widely distributed in the boreo-nemoral forest zone.

\section{Polia discalis (Grote, 1870)}

Mamestra discalis Grote, 1877, In: Uhler, Bulletin of the U.S. Geological E Geographical Survey Territories 3: 797. Type locality: Clear Creek Canyon (U.S., Colorado).

Taxonomic notes. $P$. discalis and $P$. piniae are sister species according to the morphological characters and also to the $\mathrm{CO} 1$ sequence. Abdominal coremata are present, the bundles of bristles on the left saccular process are separated, vesica with subbasal and medial diverticula. In female genitalia two signa are present only, while $P$. piniae has two stronger, stripe-like and two weaker signa.

\section{Polia piniae Buckett \& Bauer, 1967}

Polia piniae Buckett \& Bauer, 1967, Journal for Research of Lepidoptera 5: 221. Type locality: Johnsville, Plumas Co., California (Davis).

Taxonomic notes. This species and the former one are externally extreme similar. The female genitalia show the most constant differential characters.

\section{Polia nimbosa (Guenée, 1852)}

Aplecta nimbosa Guenée, 1852, Histoire Naturelle des Insectes (Lépidoptères) 6: 77. Type locality: "Amerique Septentrionale".

Taxonomic notes.This species shows nearly the same colour variations as $P$. nebulosa and it was considered by Heydemann (1944) as subspecies this species despite of the expressed differences in genitalia of both sexes and the reduction of the male brush organ. The most remarkable trend is in this species the rudimentation of the distal section of the left saccular process connected with the reduction of the distal bundle of bristles which also has some geographical variation. The species is widely distributed in the boreal and nemoral forest zones of North America and shows only some clinal variation with the exception of the Vancouver Island population (P. nimbosa mysticoides Barnes \& Benjamin, 1924; see: McCABE 1980). 


\section{Polia imbrifera (Guenée, 1852)}

Aplecta imbrifera Guenée, 1852, Histoire Naturelle des Insectes (Lépidoptères) 6: 76. Type locality: "New York".

Taxonomic notes. This species shows some simplification of the saccular processes with the reduction of the distal bundle of bristles on the left side. It means that the genital capsule secondarily seems to be more symmetrical than in other species of the nebulosa-group. It is widely distributed in the boreal and nemoral forest belts of North America and shows some clinal variation in colouration (McCABE 1980).

\section{DISCUSSION}

\section{Morpho-taxonomical and phylogenetic considerations}

In this survey, we focused on the sister species and species group relations within the subgenus Polia of the diverse and phylogenetically articulated genus Polia. We used a combination of the traditional genital morphological matrix and the consensus tree based on the available CO1 sequences (ZAHIRI et al. 2014 and GenBank, http://ncbi.nlm.nih.gov/).

Based on the genital morphological characters, our first statement was that Polia s.str., other subgenera as Metallopolia, Atropolia and Protopolia but also Pachetra together are forming a higher monophyletic unit. This result was also supported by the CO1 tree to some extent. According to CO1 data, however, Pachetra and Atropolia appear as outgroup of Polia s.str. which later proved to be monophyletic. Thus, our first question whether Polia s.str. should be considered as a monophyletic taxonomic unit was answered. Within this group, we have found a basal split between the $P$. nebulosa species group as opposed to all other species groups. Although the monophyly of the P. nebulosa group was fully supported, the subdivision of the other species groups was more complicated. While the basal split of $P$. hepatica was shown with rather low support, some other species groups seem to be strictly monophyletic. The most close relationship was found in the Holarctic arcto-alpine species "triplet" P. richardsoni - P. rogenhoferi-P. lamuta, in concordance with the published traditional morpho-taxonomic (Heydemann 1944, McCabe 1980) and CO1 (ZAHIRI et al. 2014) results. We also could confirm the monophyly of the Holarctic-temperate nebulosa species group with high support, in which the polytypic trans-Palaearctic $P$. bombycina can be opposed to the Nearctic sibling pair P. purpurissata $-P$. nugatis.

The genital morphological trees show partly the same trends with the basic difference that the strictly monophyletic nebulosa species group appears to 
be the counterpart of all other Polia subgenera and Polia s.str. species groups. Although we did not weight the characters, some strong derived characters of the nebulosa-group as the well-differentiated tufts of bristles on the left saccular process, the elongate ductus bursae with funnel-shaped antrum caused some imbalance in trees. Some former taxonomic statements were, however, strongly confirmed as (i) the taxonomic position of "Polia" cherrug as Pachetra, as member of the "western" phylogenetic group, sensu Heydemann (1944) and (ii) the monophyly of the Sino-Himalayan Metallopolia. The morphological analyses also strongly supported the close relationship of the West Chinese relic species $P$. atrax with the southern Siberian mountain species $P$. tiefi and $P$. vespertilio but also with the Holarctic boreal sibling pair $P$. vesperugo $P$. propodea. This diverse group of species is closely related both to the $P$. bombycina group, but also to the arctic-boreal "triplet" of species (P. rogenhoferi, $P$. richardsoni, $P$. lamuta) which already was predicted by Heydemann (1944). All these species groups show the same type of asymmetry of saccular processes with a single brush of bristles on the left side, in some cases with a weak the bilateral symmetry of the male genital capsule.

The bilateral symmetry of the male genital capsule is a plesiomorphic but also a rather complex trait. It includes the symmetry vs. asymmetry of sclerotised parts, e.g. of the dilated clavus but mostly the shape of the saccular processes, on the one side, and the symmetry vs. asymmetry of bundles of bristles on the saccular processes, on the other. While the differentiation of the brushes of fixed bristles emerges typically on the left side, the dilatation or bifurcation but also the reduction of the distal part of saccular processes usually appears on the right side (see VARGA \& RONKAY 2013). Both trends of asymmetry were observed in different groups of species, however, mostly expressed in the nebulosa species group. This group proved to be monophyletic based on the genital morphological characters of both sexes (Figs 26-27) but mostly according to the CO1 sequence (Fig. 28). This group was already predicted (McCABE 1980) and recently shown (ZAHIRI et al. 2014) as the sister group of all other North American Polia. The rather sophisticated genital capsule is often combined with some simplifications of the vesica, e.g. the loss of the fasciculate cornuti in $P$. subcontigua (combined with an autapomorphic helicoid shape of vesica), or the reduction of the medio-lateral diverticula in $P$. serratilinea. A widespread plesiomorphic character is the presence of the abdominal brush organ of males which can be reduced in several cases in not closely related species and species groups (see in detail in the results). A completely similar situation was already described in the closely related genus Ctenoceratoda (VARGA et al. 2018) but also in the phylogenetically distant Apamea zeta-group (Noctuinae, Apameini; see Zilli et al. 2009). 
Biogeographical considerations

The next step is the analysis of the biogeographical connections of the outlined phylogenetic subdivision. One of the main questions was which are the exclusively Palaearctic species and species groups, and which are those species groups in which Palaearctic-Nearctic connections can be observed. We concluded that the highest species diversity of Polia can be observed in the boreo-temperate zone of eastern Eurasia, and most species are typical for the montane taiga belt of southern Siberia (mostly Altai and Sayan mountain systems). Some of these species, however, as P. subcontigua, P. malchani, P. vespertilio, occur also in the Southern Urals. There are three species connected with arctic and/or alpine habitats. Only one polytypic species, P. richardsoni has a more or less disrupted Holarctic range. Its sister species $P$. lamuta also shows a long-distance disjunction, it has an arctic-subarctic range in Northern Europe (P. lamuta rangnowi (Püngeler, 1909)) and mountain tundral ("goltsy") occurrences from Buryatia to Yakutia (P. lamuta lamuta). The Nearctic P. rogenhoferi occurs from the Rocky Mountains to Labrador with a seemingly huge hiatus in the boreal coniferous forest zone (see: MCCABE 1980). The disjunctions of these ranges are obviously results of a late-glacial, postglacial regression and fragmentation due to the expansion of the Holarctic taiga zone.

A trans-Beringian disjunction was also observed in the possible sister species pair Polia propodea and P. vesperugo. While the former species is relatively rare and recognised relatively late (described by MCCABE in 1980), its Palaearctic counterpart has a huge but probably scattered range from Northern Fennoscandia to the Russian Far East and is subdivided to at least three larger population groups described as subspecies. However, the bulk of the mountain taiga faunal complex (P. tiefi, $P$. vespertilio, $P$. malchani) and also the mountain steppic $P$. serratilinea did not reach Beringia. It means that they could not be allied to the so-called mammoth steppe faunal assemblage. Comparing the distribution of the boreal forest and steppic, vs. the arctic-subarctic tundral species of some highly diverse genera, as Xestia Hübner, 1818 s.l. (including Pachnobia Guenée, 1852 Anomogyna Staudinger, 1871, Schoeyenia Aurivillius, 1883, Estimata Kozhanchikov, 1923, Raddea Alphéraky, 1892) or Anarta Ochsenheimer, 1816 s.l. (including Coranarta Beck, 1991, Hadula Staudinger, 1889, Calocestra Beck, 1991, Cardiestra Boursin, 1963, Aglossestra Hampson, 1905), we can conclude that the faunal complexes associated with taiga, boreo-montane forests and steppe (prairie) habitats show only scarce data of occurrence in Beringia, which refer - concerning this biogeographical group - only on a limited exchange during the Upper Pleistocene between the Nearctic and Palaearctic. In tundral habitats, in contrast, there are abundant 
data on trans-Beringian faunal exchanges (Lafontaine \& Wood 1988, MikKOLA et al. 1991).

Two other species groups of Polia have Holarctic distribution and show more ancient splits. The three species of the bombycina species group are clearly differentiated with high support both from the former species groups and from each other, as well, and also have sizeable intraspecific variation within their fairly widely extended ranges. All these facts suggest that the ancestor of the Nearctic sister species had crossed Beringia in a relatively early temperate phase of the Upper Tertiary and consequently should have had enough time for divergence and geographical differentiation.

The CO1 dendrogram shows that the oldest Trans-Beringian wave was most probably connected with the ancestor of the Nearctic species of the nebulosa species group, however. We have multiple evidence for this postulate as follows:

At first: there is a considerable differentiation among and within the Eurasiatic species. Polia goliath, described originally as "Dichonia", strikingly differs externally from all other known Polia species. Moreover, its three major geographical population groups ( $i$, Russian Far East + Japan and Korea, ii, Mountains of West China: Sichuan and Shaanxi, iii, Taiwan) are clearly differentiated, especially the actually unnamed subspecies occurring in Taiwan. Although $P$. nebulosa and $P$. lama are externally rather similar, both species have autapomorphies, like the dentate crest on the left saccular process in $P$. nebulosa or the reduction of the abdominal brush organ in P. lama. Furthermore, both species show mentionable intraspecific geographical differentiation (VARGA et al. 2019).

At second: there is a highly supported very deep split between $P$. nebulosa and all North American species despite the external similarity with some Nearctic species as Polia discalis (Grote, 1870) and Polia piniae Buckett et Bauer, 1967. These species represent an obviously monophyletic lineage.

At third: there is a considerable differentiation among the four Nearctic species, with the highest support between $P$. imbrifera and the other three species. However, all these specific splits have very probably pre-glacial origin due to the sharp differentiation of the $\mathrm{CO} 1$ gene. All these evidence support our hypothesis that Trans-Beringian migrations should have occurred at least three times in the zoogeographical history of Polia.

Acknowledgements - The authors are grateful to Péter Gyulai (Miskolc, Hungary), Sabine Gaal-Haszler, Martin Lödl (Naturhistorisches Museum, Vienna), Axel Hausmann, Ulf Buchsbaum (Zoologische Staatssammlung, Munich), Martin Honey, Alberto Zilli (The Natural History Museum, London), Wolfram Mey (Museum für Naturkunde, Berlin), 
Robert Trusch, Michael Falkenberg (Landessammlungen für Naturkunde, Karlsruhe) for the possibility of study valuable collection materials, including types. Our sincere thanks to Peter Huemer (Tiroler Landesmuseum, Hall in Tirol) for important information on molecular taxonomic data. We are indebted to Lórántné Csenkey (HNHM Budapest), Ádám Kiss (HNHM Gyöngyös) and Péter Kozma (University of Debrecen) for technical assistance.

Present survey was financially supported by the K 116694 grant of the National Foundation of Research, Development and Innovation (NKFI-OTKA); also OTKA T16465 and OTKA T73597 (Z. Varga) and by the SYNTHESYS Project which is financed by European Community Research Infrastructure Action under the FP6 "Structuring the European Research Area" Programme; Grants Nos: NL-TAF 3007 and DE-TAF-6708 (Z. Varga); GBTAF-2644, DE-TAF-3514 and AT-TAF-5609 (G. Ronkay); GB-TAF-2656, FR-TAF-562 and SETAF-6919 (Stockholm) (L. Ronkay).

\section{REFERENCES}

Bouckaert, R. R., Heled, J., Kuehnert, D., Vaughan, T. G., Wu, C. H., Xie, D., Suchard, M. A., Rambaut, A. \& Drummond, A. J. (2014): BEAST 2: A software platform for Bayesian evolutionary analysis. - PLoS Computational Biology 10: e1003537 https://doi. org/10.1371/journal.pcbi.1003537

Boursin, Сн. (1964): Lepidoptera der Deutschen Nepal-Expedition 1955 II. NoctuidaeTrifinae. - Veröffentlichungen aus der Zoologischen Staatssammlung München 8: 1-40 + Taf. I-XXIII.

CAstresana, J. (2000): Selection of conserved blocks from multiple alignments for their use in phylogenetic analysis. - Molecular Biology and Evolution 17: 540-552. https://doi. org/10.1093/oxfordjournals.molbev.a026334

Charif, D. \& Lobry, J. R. (2007): SeqinR 1.0-2: a contributed package to the R project for statistical computing devoted to biological sequences retrieval and analysis. Pp. 207-232. In: Bastolla, U., Porto, M., Roman, H. E. \& Vendruscolo, M. (eds): Structural approaches to sequence evolution. Biological and Medical Physics, Biomedical Engineering. Springer, Berlin. https://doi.org/10.1007/978-3-540-35306-5_10

Drummond, A. J. \& RAmbaut, A. (2007): BEAST: Bayesian evolutionary analysis by sampling trees. - BMC Evolutionary Biology 7: 214. https://doi.org/10.1186/1471-2148-7-214

Gernhard, T. (2008): The conditioned reconstructed process. - Journal of Theoretical Biology 253: 769-778. https://doi.org/10.1016/j.jtbi.2008.04.005

Hacker, H., Ronkay, L. \& Hreblay, M. (2002): Hadeninae I. In: Fibiger, M. (ed.): Noctuidae Europaeae, vol. 4. - Entomological Press, Sorø, 456 pp.

Heydemann, F. (1944): Zur Kenntnis der Gattung Aplecta Guen. und zweiter „Dual Species" inderselben (Lep. Noct.). - Entomologische Zeitung des Entomologischen Vereins zu Stettin 105: 12-33.

Huemer, P., Mutanen, M., Sefc, K. M. \& Hebert, P. D. N. (2014): Testing DNA barcode performance in 1000 species of European Lepidoptera: large geographic distances have small genetic impacts. - PLoSOne 9: e115774 https://doi.org/10.1371/journal. pone. 0115774

Катон, K. , Kuma, K. I., Тон, H. \& Miyata, T. (2005): MAFFT version 5: improvement in accuracy of multiple sequence alignment. - Nucleic Acids Research 33: 511-518. https:// doi.org/10.1093/nar/gki198 
Kononenko, V. S. (1990): Synonymic check list of the Noctuidae of the Primorye Territory, the Far East of U.S.S.R. - Tinea 13(Suppl.): 1-40.

Kononenko, V. S., Lafontaine, J. D. \& Mikкola, K. (1989): An annotated checklist of noctuid moths (Lepidoptera, Noctuidae) of Beringia. - Entomologicheskoe Obozrenie 68: 549-567. Reprinted in English in Entomology Review 69: 117-138, 1990.

Kononenko, V. S., Lafontaine, J. D. \& Mikкola, K. (1996): Taxonomy and zoogeography of some arctic Noctuidae (Lepidoptera), with descriptions of three new species and one new subspecies. In: Relations between arthropod faunas of Northern Europe, Siberia and Central Asia. 2. Lepidoptera. - Acta Zoologica Fennica 200: 83-94.

Lafontaine, J. D. \& Kononenko, V. S. (1988): A revision of the Lasionycta skraelingia (Herrich-Schäffer) species complex (Lepidoptera: Noctuidae). - Canadian Entomologist 120: 903-916. https://doi.org/10.4039/Ent120903-10

Lafontaine, J. D., Mikкola, K. \& Kononenko, V. S. (1983): A revision of the genus Xestia subg. Schoeyenia Aurivillius (Lep.: Noctuidae) with descriptions of four new species and a new subspecies. - Entomologica Scandinavica 14: 337-369. https://doi. org/10.1163/187631283X00353

Lafontaine, J. D., Mikкola, K. \& Kononenko, V. S. (1987): A revision of the genus Xestia subg. Pachnobia (Lep.: Noctuidae) with descriptions of two new subspecies. - Entomologica Scandinavica 18: 305-331.

Lafontaine, J. D. \& Wood, D. M. (1988): A zoogeographic analysis of the Noctuidae (Lepidoptera) of Beringia, and some inferences about past Beringian habitats. Memoirs of the Entomological Society of Canada 144: 109-123. https://doi.org/10.4039/ entm120144109-1

Lewis, P. O. (2001): A likelihood approach to estimating phylogeny from discrete morphological character data. - Systematic Biology 50: 913-925. https://doi. org/10.1080/106351501753462876

McCabe, T. M. (1980): A reclassification of the Polia complex for North America (Lepidoptera: Noctuidae). - New York State Museum, Bulletin No. 432. i-vi, 1-141 pp.

Mikkola, K., Lafontaine, J. D. \& Kononenko, V. S. (1991): Zoogeography of Holarctic species of Noctuidae (Lepidoptera): importance of the Beringian Refuge. - Entomologica Fennica 2: 1-17. https://doi.org/10.33338/ef.83545

Paradis, E., Claude, J. \& Strimmer, K. (2004): APE: analyses of phylogenetics and evolution in R language. - Bioinformatics 20: 289-290. https://doi.org/10.1093/bioinformatics/btg 412

Rambaut, A. \& Drummond, A. J. (2016): TreeAnnotator v1.8.3. - University of Edinburgh, Edinburgh, UK. http://beast.bio.ed.ac.uk/treeannotator

Rambaut, A., Drummond, A. J., Xie, D., Baele, G. \& Suchard, M. A. (2018): Posterior summarisation in Bayesian phylogenetics using Tracer 1.7. - Systematic Biology 67: 901-904. https://doi.org/10.1093/sysbio/syy032

R Development Core Team (2017): R: A language and environment for statistical computing. R Foundation for Statistical Computing, Vienna, Austria. http://www.R-project.org/

SchlieP, K. P. (2011): phangorn: Phylogenetic analysis in R. - Bioinformatics 27: 592-593. https://doi.org/10.1093/bioinformatics/btq706

StAмAтAKIS, A. (2006): RAxML-VI-HPC: maximum likelihood-based phylogenetic analyses with thousands of taxa and mixed models. - Bioinformatics 22: 2688-2690. https:// doi.org/10.1093/bioinformatics/btl446 
VARGA, Z. \& RonkAY, L. (2013): Structural constraints of secondary asymmetry in male external genitalia of Noctuidae. - Insect Systematics \& Evolution 44: 349-372. https://doi. org/10.1163/1876312X-04402001

VARga, Z., Ronkay, G. \& RonkAY, L. (2017): Revised taxonomic check list of the Eurasiatic species of the subtribe Poliina (Noctuidae, Noctuinae, Hadenini). - Deutsche Entomologische Zeitschrift 64(2): 133-160. https://doi.org/10.3897/dez.64.21455

Varga, Z., Ronkay, G. \& Ronkay, L. (2018): Metallopolia, a new subgenus of Polia (Noctuidae, Noctuinae, Hadenini), with the description of two new species and a new subspecies. - Journal of Asia-Pacific Entomology 21: 217-232. https://doi.org/10.1016/j. aspen.2017.12.005

Varga, Z., Ronkay, G. \& Ronkay, L. (2019): Taxonomic survey of the Polia (Polia) nebulosa species complex (Noctuidae, Noctuinae, Hadenini) with the description of two new subspecies. - Acta Zoologica Academiae Scientiarum Hungaricae 65(2): 107-122. https:// doi.org/10.17109/AZH.65.2.107.2019

Zahiri, R., Lafontaine, J. D., Schmidt, B. C., deWaArd, J. R., Zakharov, E. V. \& Hebert, P. D. N. (2014): A transcontinental challenge - A test of DNA barcode performance for 1,541 species of Canadian Noctuoidea (Lepidoptera). - PLoS ONE 9(3): e92797. https://doi.org/10.1371/journal.pone.0092797

Zilli, A., Varga, Z., Ronkay, G. \& Ronkay, L. (2009): Apameini I. A taxonomic atlas of the Eurasian and North African Noctuoidea. Vol. 3. - Heterocera Press, Budapest, 393 pp.

Received May 4, 2019, accepted September 10, 2019, published March 6, 2020 


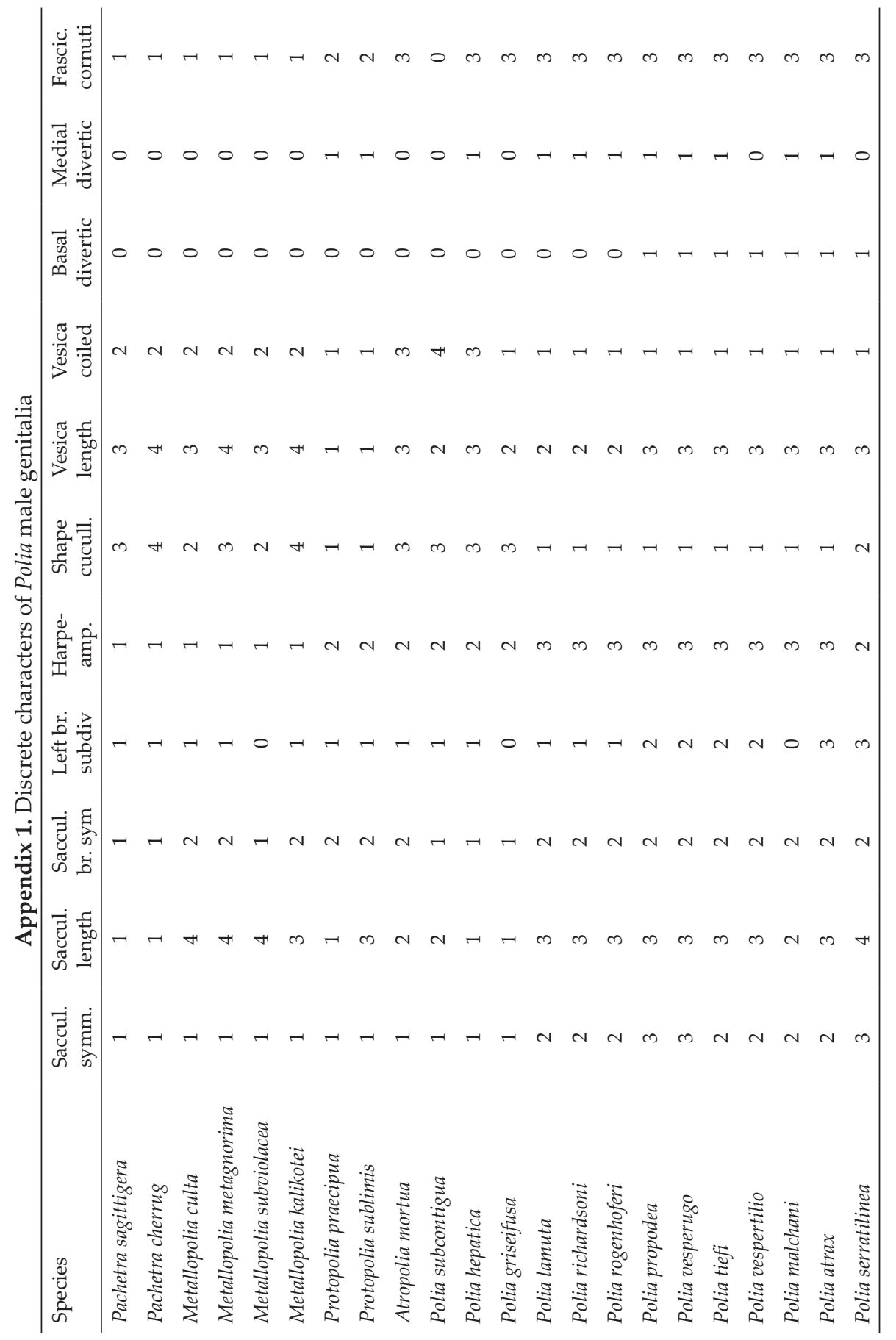




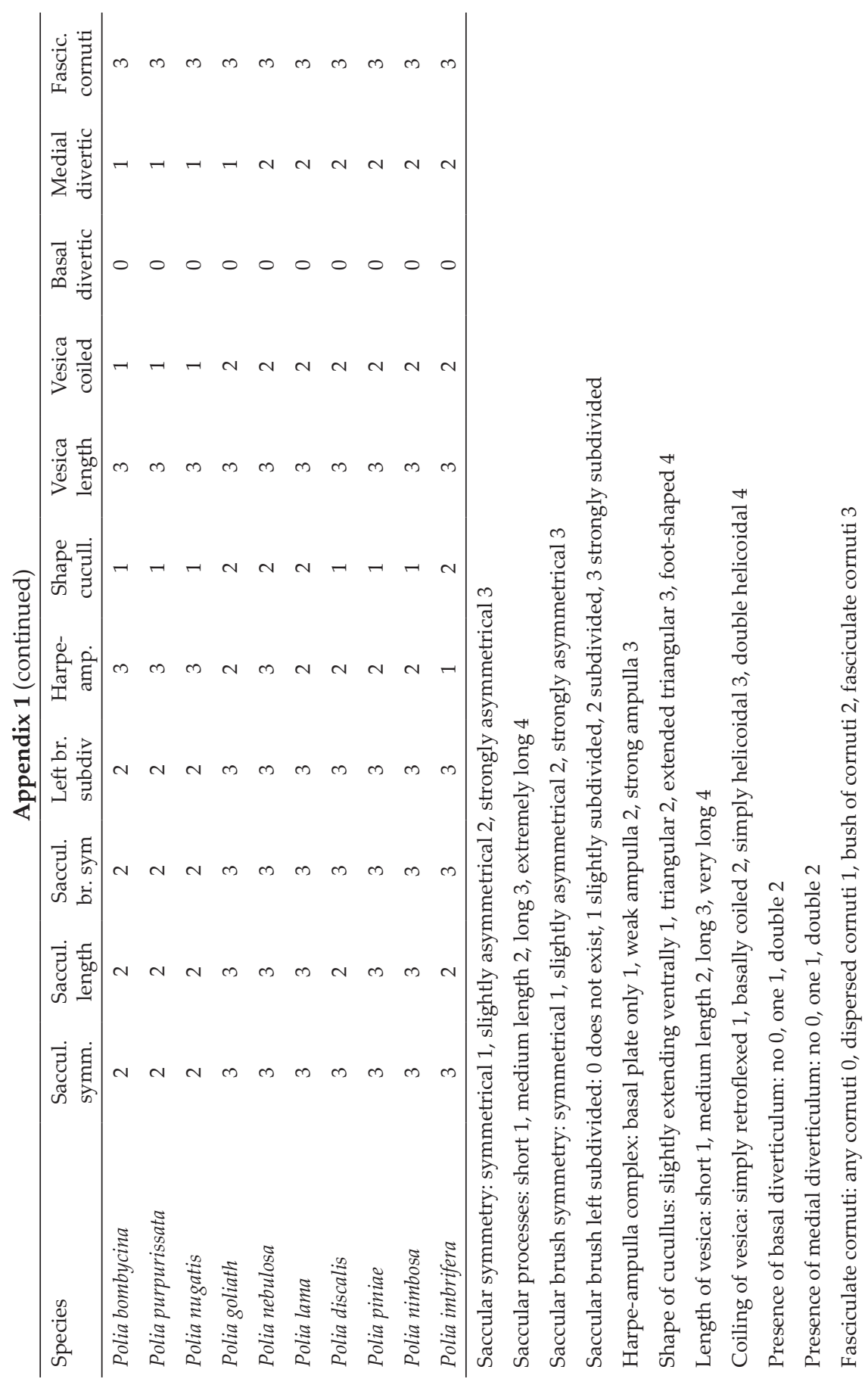




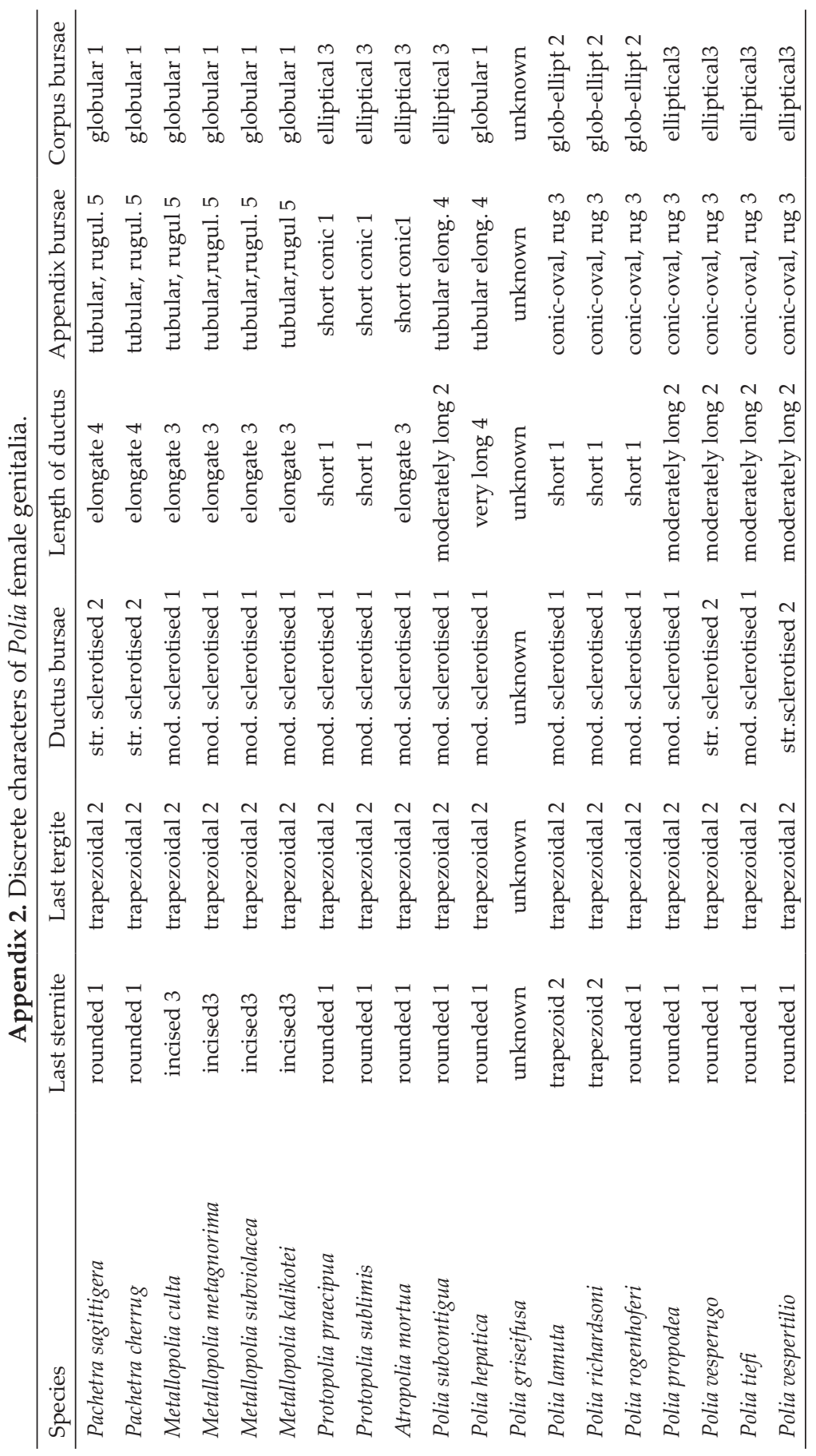




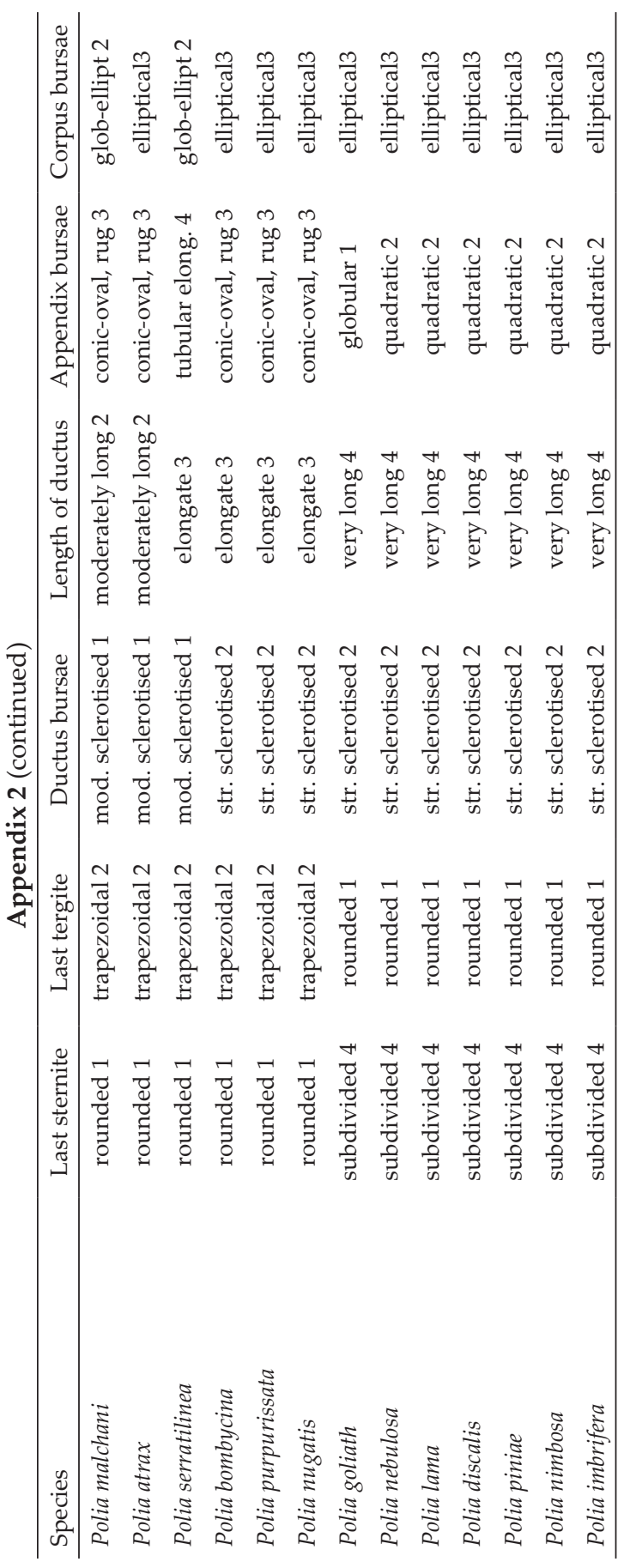


